\title{
Factors Affecting Non-Performing Loans in Commercial Banking Sector: A Comparative Study of Public and Private Banks A Case Study of Commercial Bank of Ethiopia and Dashen Bank District in Southern Region of Ethiopia
}

\author{
Negalign Nigatu Oynaka \\ MSC in Accounting and Finance, Lecturer in Wolaita Sodo University
}

\begin{abstract}
The study aims to identify factors affecting non-performing loans in commercial banking sector; in public and private banks of the study area. To achieve the "general and specific objectives" the study was look institutional and customer specific factors affecting NPLs and the remedial practices can be implemented to reduce the level of NPLs. This study also used descriptive research design and quantitative research approach were used and the primary source of data were collected from 52 credit staff members from CBE and Dashen banks District in Southern Region. The sampling techniques were purposive sampling method. However, the sample was selected from credit staff only. For data analysis, descriptive statistics including mean, std. deviation, frequency and percentages were used. The results of the study indicated Bank specific factors include Bank size and performance, credit size, poor credit assessment, poor credit terms, lack of aggressive credit collection system, inadequate nature of collateral were identified as bank specific factors affecting NPLs. On the other hand unwillingness of borrower to pay back loan, customers funds diversion for unexpected purpose were identified as customer specific factors affecting NPLs. Hence, to reduce the occurrence of loan default it is suggests the stakeholders in the credit system including the banks and government must implement policies that will facilitate the minimization of the internal as well as external factors that precipitate NPLs.
\end{abstract}

Keywords: Bank Specific Factors, Customer Specific Factors, Non-Performing Loans

DOI: $10.7176 /$ RJFA/10-3-07

\subsection{Background of the Study}

Banks play an important role in the economic development of the world, financial institutions and banks in particular are vital to any economy due to their ability to mobilize savings and to enhance capital flows in the economy (Richard, 2011). The financial intermediary function performed by banks in any economy motivates investment and increase productivity (Hardy, 2006).

Apparently, lending is of fundamental importance to the banking industry as the loans that the banks give out form the primary sources of their revenues. In fact, it has been determined that loans provide between $50 \%$ and $75 \%$ of the revenues that banks earn. Apart from the ability of loans to produce revenues, loans are also capable of attracting the principal portion of operating income to the bank thus keeping them operational. Considering, commercial banks perceive lending as a crucial function for fund utilization. (Karim, et al., 2010).

Banks pool funds together and make them available for investment with issuing loans, thereby providing liquidity. Small business borrowers find bank lending important due to their small sizes and capacities. Enhanced bank customer relationship helps small business to access funding because the bank has got special knowledge about the firm. In difficult time, for example, economic recession, firms with strong relationship with a bank stand a better chance to obtain financing to endure the recession. Banks administer payment systems which are core to an economy. Through payment system, banks execute customer's payment instruction by transferring fund between their accounts. Banks are the transmission belt for monetary police (Richard, 2011).

According to directives of National Bank of Ethiopia "loans" or advances" means any financial asset of the bank arising from the direct or indirect advances by a bank to a person that are conditioned on the obligation of the person to repay the fund, either on a specified date or dates usually within interest (Directives of National Bank of Ethiopia SSB/43/2008).

Lending is not an easy task for banks because it involves risk of non-repayment which in banking terminology labeled as non-performing loans. Non- performing loans" means outstanding credit facilities that are past due for more than 90 days beyond the agreed-upon the repayment period, non-performing loans are loans that are ninety or more days delinquent in payments of interest and/or principal or loans categorized under substandard, doubtful and loss as groupings of unpaid loans (NPL). Non-performing loans are closely associated with banking crises. The reason given by different banks vary according to their less quality asset performed, but in common, there are internal and external factors that cause it.

This study was attempted to identify factors affecting non-performing loans in commercial banking sector; public and private banks, a case of CBE and Dashen Bankin WolaitaSodo and Hawassa Districtin Southern Region of Ethiopia. This study proved critical in bridging the knowledge gap to facilitate the managers in 
monitoring the causes of non-performing loans. It helps the managers fine tune their remedial strategies to implement for a better effective results and reduce the non-performing loans.

\subsection{Statement of the problem}

Non-performing loans affect the bank's liquidity and profitability which are the main components for the overall efficiency of the bank. The level of loan default increase in banking industry it reduces the possibility of generating income in order to maximize the profitability the banks. Again, mismatch of maturities between asset and liability create liquidity risk for the banks that deteriorate bank's overall credit rating including its image or goodwill (Badar and Yasmin, 2013).Therefore, the determinants of NPLs should be given a due consideration because of its argumentative effect on survival of banks. The adverse effect of NPL is attributable to bank manager's hostile selection of its borrowers (Brownbridg 1998).

Increasing level of non-performing loans may lead to very serious effects. For instance, it discourages the financial institution to refinance the defaulting client, which put the defaulters once again into vicious circle of low productivity. Therefore, an irregular investigation of the various aspects of loan defaults, source of credit, purpose of the loan, type of loan, and condition of loan provisions etc., are of utmost importance both for policy makers and the lending financial institutions. Even if default is random and influenced by unpredictable behavior or it is influenced by certain factors in a specific situation needs an empirical investigation. Such close observations would aid all financial institutions to manipulate their credit program for the better.

Most of the defaulters were found to be the root cause of laxity in management procedures, loan diversion and un-willingness to repay loans, etc. Due to such irregularities, lenders need to be careful in following stringent norms predetermined and ensure in overcoming such risks and if not at least reduce the risk of loan default (Ahmmedet al., 2012).

The seeds of present study are sowed in attempting to find major influencing factors or bottlenecks that increase non-performing loans in both public and private banks of Ethiopia. It is believed that the causes for nonperforming loans would vary in depending on the bank size and performance, credit size, poor credit assessment, terms of credit, credit orientation, high credit growth and risk appetite, and poor monitoring among others. To facilitate the present study, the causes of non-performing loans are categorized into two: bank specific and customer specific variables.

Bank failures come with massive effects and costs not only to Banks but also to the economy as a whole. This, being the immediate reason of Banking crisis occurrences at various times indicates that assessment of non-performing loans and implementation of controlling mechanisms to avoid their occurrence is a continuous process which should be improved from time to time. However, credit risk management is indeed a very difficult and complex task in the financial industry because of the unpredictable nature of the macroeconomic factors coupled with various microeconomic variables which are peculiar to the banking industry or specific to a bank (Garr, 2013).

In privies most studies focused on determinants of non-performing loans in commercial banking industries in Ethiopia and in the other country are categorized the factors in to bank specific and macro-economic variable. There was no study conducted so far in southern region on this issue, however there was an attempt made on other regional and national levels.

Therefore, this study may prove critical in bridging the knowledge gap by identifying the factors that cause non-performing loans and facilitate appropriate measures to avoid their occurrence and attempts to provide answers for the following basic research questions;

1. What are institutional specific factors affecting Non-performing loans in public and private banks in the selected area?

2. What are customers specific factor affecting non-performing loan in public and private banks in the selected area?

3. What are the remedial practices can be implemented to reduce the level of non-performing loans in public and private banks in the selected area?

\subsection{Research Objective}

The general objective of this study is to identify factors affecting non-performing loans in commercial banking sector; between public and private banks in the selected area.

Based on the above stated general objective the following specific objectives are drawn:

1. To assess institutional specific factors affecting non-performing loans in public and private banks in the selected area.

2. To examine customers specific factors affecting non-performing loan in public and private banks in the selected area.

3. To evaluate some of the remedial practices can be implemented to reduce the level of non-performing in public and private banks in the selected area. 


\subsection{Review of related literature}

\subsubsection{Theoretical and conceptual literature review}

\subsubsection{Concepts of Non-Performing Loans}

The concept of non-performing loans has been defined in different literatures. According to (Patersson and Wadman2004), non- performing loans are defined as defaulted loans which banks are unable to profit from. They are loans which cannot be recovered within stipulated time that is governed by the laws of a country.

According to National Bank of Ethiopia's (NBE's) Directive no, SSB/43/2008, "Non- performing loans" means outstanding credit facilities that are past due for more than 90 days beyond the agreed-upon the repayment period, non-performing loans are loans that are ninety or more days delinquent in payments of interest and/or principal or loans categorized under substandard, doubtful and loss as groupings of unpaid loans (NPL).

\subsubsection{Institutional Specific Factors Affecting NPL}

(Richard 2011) observes that there are endogenous forces inherent in the banks institutional processes that influence the levels of NPLs. The bank specific factors affecting NPL to be identify as; bank size and performance, credit size (such as aggressive lending, compromised integrity in approval, rapid credit growth, bank great risk appetite), poor credit assessments, poor credit loan monitoring and loan supervision capacity, lenient/lax credit term, lack of aggressive credit collection police, inadequate nature of collateral are the major factors affecting non-performing loan in the side banks.

\subsubsection{Customers Specific Factors Affecting Non-Performing Loans}

Kanimbla (2010) studied determinants of non- performing loans in Standard Charted Bank. He argued that long duration granted for repayment of loans, unwillingness of borrowers to pay back the loan, lack of business skills are the reasons for non-performing loans.

Gaitho Edna (2010) in his study the causes of non-performing loans in Kenyan banks, he reveled that in the side of customer specific factors like Bank clients started new businesses in which they had no experience, The simultaneous operation of too many kinds of business, The inappropriate use of the loan, Debtors conceal some vital data in their applications, Provision of poorly valued collateral or difficulties in recovery, All these factors were found to contribute to bad loans.

Kwayu (2011) analyzed factors for non- repayment of bank loans at NBC Dodoma region in Tanzania. The attitudes of borrowers contributed to non-repayment of loans are high.

Carlo Msigwa(2013) studied Factors affecting non-performing loans in Banking industry: A case of KCB Bank (Tanzania) Limited; Morogoro and Msimbazi Branches. The findings showed that, diversion of funds for unnecessary expansion of business and speculations leading to investing in high risk assets to earn high income and legal environment which reflects the availability or non-availability of foreclosure laws and ownership rights for both domestic and foreign investors have been factors influencing NPLs.

Stephen Laurent Isaac Mwakajumilo(2014) conducted to assess the impact of non-performing assets on the growth of banking industry in Tanzania specifically NMB Bank. The findings revealed that the impact of nonperforming assets facilitated by non-recovery of loans hence caused great harm to the economic framework and structure, loss of trust of dishonest, reduced customer ability in buying, legal issues.

\subsubsection{Remedial Mechanisms of Dealing with Non-Performing Loans}

The impact of non-performing loans on any bank or economy can be devastating, it is therefore important that non-performing loans are controlled to ensure that the banks remain functional and profitable (Guy, 2011). Proper credit management is necessary to prevent banks from taking unnecessary and excessive risks that may lead to the accumulation of NPLS (Brownbrigde, 2007). Therefore, it is apparent that proper control and management of non-performing loans has positive results to the banks, firms and even to the general economy. The impact of non-performing loans on any bank or economy can be devastating, it is therefore important that non-performing loans are controlled to ensure that the banks remain functional and profitable (Guy, 2011). Proper credit management is necessary to prevent banks from taking unnecessary and excessive risks that may lead to the accumulation of NPLS (Brownbrigde, 2007). Therefore, it is apparent that proper control and management of non-performing loans has positive results to the banks, firms and even to the general economy. Miscarriages in the management of loans naturally lead to a surge in the levels of non-performing loans (Richard, 2013). Following is an assessment of literature on the mechanisms that can be implemented to deal with NPLs.

\subsubsection{Empirical Evidence}

This section presents evidence which identify the major factors of nonperforming loans. Many researchers have conducted a lot of study on determinants of nonperforming loans (NPLs), due to its significance for the bank's failure. Accordingly, the first subsection, presents factors affecting nonperforming loans in cross countries. The second subsection discusses review of prior studies on factors of non-performing loans in Africa and the last empirical evidence in Ethiopia.

\subsubsection{Cross Countries}

MwanzaNkusu (2011) analysed the linkage between nonperforming loans and macroeconomic performance of 26 advanced economies from 1998 to 2009. In his study, only macroeconomic variables were introduced. 
Specifically, GDP growth, unemployment, change in the house price index, change in the equity price index, inflation, nominal effective exchange rate, policy rate of interest and credit to the private sector were included in his empirical specification. His findings revealed that a poor macroeconomic performance (Slower GDP growth, higher unemployment or decreasing asset prices) could be associated with increasing non-performing loans in advanced economies.

Bock and Alexander Demyanets (2012) analyzed the determinants of bank asset quality in 25 emerging countries during 1996-2010, by examining only aggregate macroeconomic and credit indicators. Their findings present that GDP growth rate, exchange rates and loan growth are the main determinants of non-performing loans in the examined countries.

Vasilikiet.al (2014) analyzed the Determinants of Non-Performing Loans the Case of Eurozone, their findings largely agree with bank-specific variables, the rate of non-performing loans of the previous year, the capital ratio and ROE appear to exert a powerful influence on the non-performing loans rate. At the same time, from macroeconomic perspective, public debt, GDP and unemployment seem to be three additional factors that affect the NPL index, unveiling that the state of the economy of Eurozone countries is clearly linked to loan portfolio quality.

Ming-Chang, et.al (2016), study on Factors affect NPL in Taiwan Banking Industry This study examines whether government policies have an impact on non-performing loans (NPL)ratio of domestic banks during dissimilar financial periods from 1994 to 2008. The influence variables in the NPL ratio include loan to deposit ratio, debt ratio, bank size (Asset), earnings per share, capital adequacy ratio (Basel ratio) and directors and supervisors shareholding ratio are the main cases for the occurrences of non-performing loans.

\subsubsection{Empirical Studies in Africa}

Gaitho Edna (2010) in his study the causes of non-performing loans in Kenyan banks, he reveled that bank specific factors such as Lax procedures used for credit risk assessment, lack of trained lending personnel ,Lack of aggressive credit collection methods ,Banks negligence in monitoring performing loans, The speedy consideration in granting process, Insider lending and owner concentration and in the side of customer specific factors like Bank clients started new businesses in which they had no experience, The simultaneous operation of too many kinds of business, The inappropriate use of the loan, Debtors conceal some vital data in their applications, Provision of poorly valued collateral or difficulties in recovery, All these factors were found to contribute to bad loans.

Din'ohi (2011) who conducted research on factors that increased the level of non- performing loans at AKIBA commercial bank in Tanzania concluded that poor practicing of credit policies and procedure, unavailability of accurate information were positively related to non- performing loans.

MonicahWanjiru (2011) conducted research on causes of Non-Performing loans in Commercial Banks in Kenya, revealed that non-performing loans of commercial banks in Kenya are positively correlated with inflation rate and non-performing loans are negatively correlated with real interest rate and growth rate in loans respectively. The macroeconomic independent variables also found that the non-performing loans were positively correlated to inflation rate. Further his concludes that non-performing loans are negatively correlated with real interest rate and growth rate in loans in Kenya.

Carlo Msigwa(2013) studied Factors affecting non-performing loans in Banking industry: A case of KCB Bank (Tanzania) Limited; Morogoro and Msimbazi Branches. Their study can be expressed as factors affecting non-performing loans are the function of political lobbying and administrative pressure, private corruption/fraudulent practices, bank size and performance, credit culture, market changes, legal environment, individual's/entity's capacity, speculation, macro-economic factors and internal and external factors. The findings showed that, diversion of funds for unnecessary expansion of business and speculations leading to investing in high risk assets to earn high income and legal environment which reflects the availability or nonavailability of foreclosure laws and ownership rights for both domestic and foreign investors have been factors influencing NPLs.

Stephen Laurent Isaac Mwakajumilo(2014) conducted to assess the impact of non-performing assets on the growth of banking industry in Tanzania specifically NMB Bank. The findings revealed that the impact of nonperforming assets facilitated by non-recovery of loans, hence caused great harm to the economic framework and structure, loss of trust of dishonest, reduced customer ability in buying, legal issues, lack of aggressive credit collection policy, poor credit assessment.

\subsubsection{Empirical Studies in Ethiopia}

TeshomeDula(2010) conducted on NPL and its Management in commercial bank in Ethiopia a case Dashen bank Mekelle area bank he conclude that Regarding the factors that cause nonperforming loan from the borrower side, the findings of the study shows that lack of sufficient income, lack of proper education on the business area they engaged, lack of saving account, absence of sufficient infrastructure, lack of sufficient supervision from the bank, high consumption expenditure, and high interest charge are the factors identified but lack of sufficient income(market problem), lack of proper education, lack of sufficient infrastructure and lack of sufficient 
supervision from the bank are the main problems. Also there are factors that cause NPL from the lending institution side like Ineffective monitoring of loans, delayed loan approval and poor credit appraisal.

AnisaUmer(2015) conducted on the Determinants of Nonperforming Loan in Ethiopian Commercial Banks, Their study period covered from 2004 to 2013. Seven factors (four bank specific and three macroeconomic factors) affecting banks nonperforming loan were selected and analyzed. Their results of balanced fixed effect panel data regression analysis showed that deposit rate, loan to deposit ratio and lending interest rate had positive and significant impact on banks nonperforming loan. According to the regression result lending interest rate is a very important determinant of nonperforming loan in Ethiopia banking industry. Cost efficiency had negative and significant impact on banks nonperforming loan. Bank solvency ratio and gross national product (GDP) growth rate and inflation rate had negative and statistically insignificant impact on banks nonperforming loan.

AregaSeyoum,A et, al (2016) conducted on factors affecting Non-performing loans of Development Bank of Ethiopia, Central Region. The result of the study shows that poor credit assessment and credit monitoring are the major causes for the occurrence of NPL in DBE. Credit size (includes aggressive lending, compromised integrity in approval, rapid credit growth and bank's great risk appetite); high interest rate, poorly negotiated credit terms and lenient/lax credit terms, and elongated process of loan approval were bank specific causes for the occurrence of nonperforming loans. On the other hand, poor credit culture of customers, lack of knowledge of borrower for the business they engaged in, willful default, loan diversion, and project management problems were identified as the major customer specific causes of NPLs.

\subsubsection{Conceptual Framework}

Accordingly, based on the objective of the study, the following conceptual model has been framed. Nonperforming loans are affected by bank specific and customer's specific factors as discus in the literature review part. Bank specific factors include Bank size and performance, credit size ( such as aggressive lending, compromised integrity in approval, rapid credit growth, bank great risk appetite), poor credit analyses and assessment, poor credit monitoring and banks loan supervision capacity, poor credit condition and lenient/lax credit terms, lack of aggressive credit collection system, inadequate nature of collateral,. On the other hand customers specific factor like unwillingness of borrower to pay back loan, customers funds diversion for unexpected purpose will be analyze as factors affecting non-performing loans.

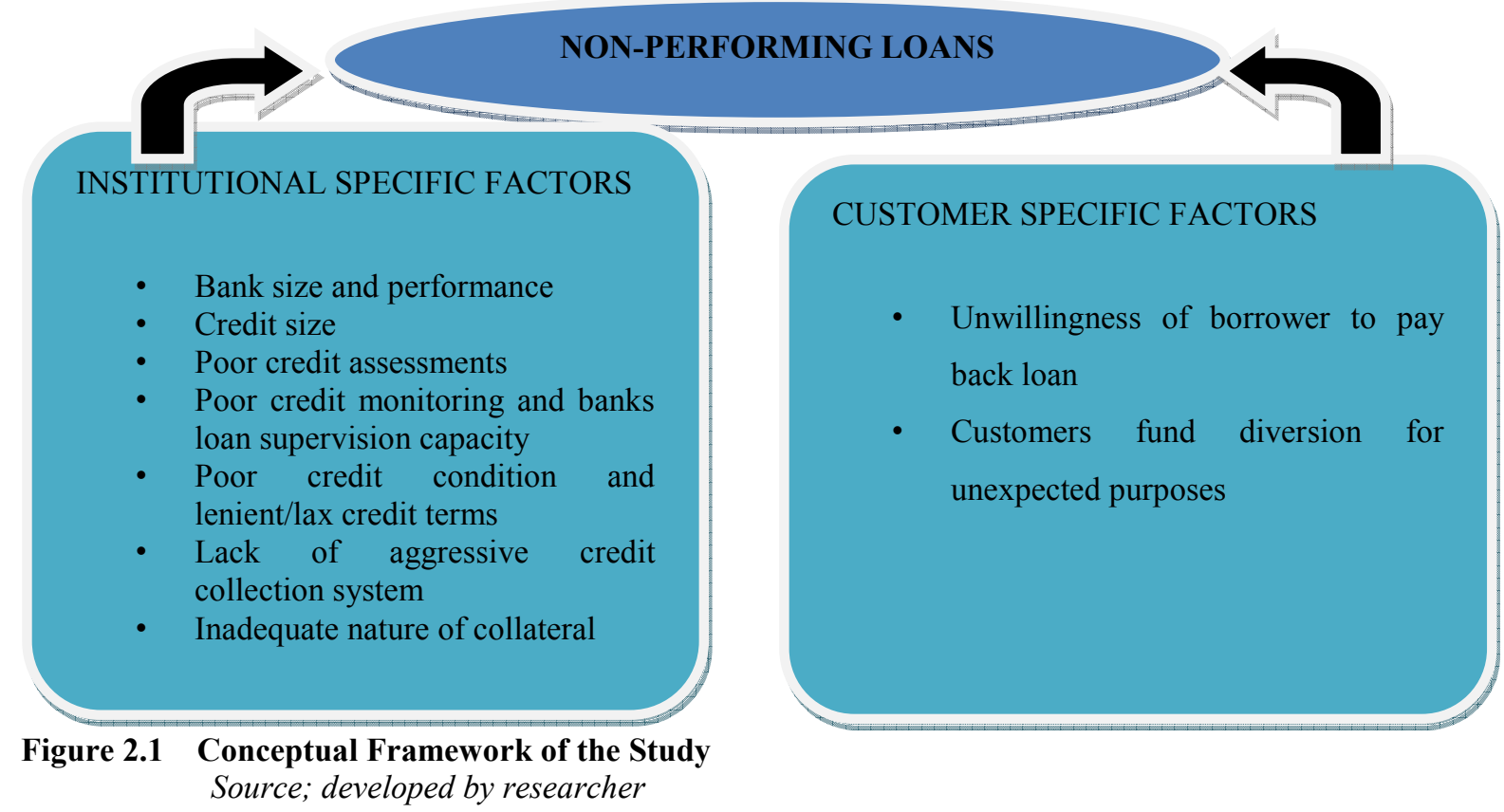

\subsubsection{Knowledge Gap Identification}

There are a plenty of variables that affect the NPLs of banking sectors. In this study, the researcher focused on both bank specific and customer specific factors affecting non-performing loans of commercial banks in Ethiopia. However, the variables that got more attention and included in this thesis were Bank size and performance, credit size (aggressive lending, compromised integrity in approval, rapid credit growth, bank great risk appetite), poor credit analyses and assessment, poor credit monitoring and banks loan supervision capacity, poor credit condition and lenient/lax credit terms, lack of aggressive credit collection system, inadequate nature of collateral, unwillingness of borrower to pay back loan, diversion of funds for unexpected purpose. In view of the above discussions, several studies were conducted on the determinants of Non-performing loans. Most of the previous studies focused on Bank specific and Macro-economic determinates of NPL. Thus, as to the knowledge of the 
researcher, there is still limited number of literatures in Ethiopian banking industry.

In accordance with the above discussions, majority in the previous studies focused on similar Bank specific variables but in this study the researcher find the gap from empirical literature outside Ethiopia, is lack of aggressive credit collection polices are bank specific variables this variables cannot identified by previous studies in Ethiopia. Therefore, this study is expected to fill the gap by identify the variable that causes for the occurrence of nonperforming loans.

\subsection{Research Methodology}

The research designs adopted in this research were descriptive research design. This type of research is commonly conducted to collect detail description of existing phenomena with the intent of employing data to justify current conditions and whenever possible to draw valid general conclusion from the facts discovered.

The research approaches adopted in this research were quantitative research strategies or tools that are relevant to achieve the desired research outcome based on survey design with structured close-ended questionnaires.

The target population in this study ware all staff members who were engaged in credit area of surveyed banks specifically (CBE) and Dashen bank districts in southern region of Ethiopia.

The sample was constructed from opinion view of public (CBE) and Private Dashen Bank District in Southern Region of Ethiopia.

The sampling technique adopted in this research was purposive sampling technique.The sample size used in this research were the total target population of staff members, who were engaged on credit area in both CBE and Dashen bank district in southern region of Ethiopia

Sample Proportion Allocation

\begin{tabular}{|l|l|l|}
\hline No & Names Of District & Number Of Respondents In Credit Staffs \\
\hline $\mathbf{1}$ & CBE Wolaita Sodo and Hawassa District & 26 \\
\hline $\mathbf{2}$ & Dashen Bank Wolaita Sodo and Hawassa District & 26 \\
\hline \multicolumn{2}{|l|}{ Total target population } & $\underline{52}$ \\
\hline \multicolumn{2}{|l|}{ Total sample size } & $\underline{2}$ \\
\hline
\end{tabular}

Source; from CBE \& Dashen banks District Human resource managements 2017

The quantitative data types with primary sources of data were employed in this study. To obtain data from every credit members, Census were adopted to collect primary sources of data. The close-ended structural questionnaires were structured and it includes the three research questions. The instruments were compressed of four parts and used five point likert scales it's better to this descriptive research study. Method of Data Analysis is Descriptive statistical analysis ware used and this analysis ware performed with SPSS. V.20.

\subsection{Results and discussion}

This study was initially aimed at collected data from 52 credit members of CBE and Dashen Bank District in Southern region.

Response Rate $=$ Number of Surveys Completed $/$ Number of People Contacted

$$
\begin{aligned}
& =52 / 52 \times 100 \\
& =100 \%
\end{aligned}
$$

1.7.1 Institutional Specific Factors Affecting NPLs

1.7.1.1 Bank Size and Performance

\begin{tabular}{|c|c|c|c|c|}
\hline \multirow[b]{2}{*}{ Item } & \multicolumn{2}{|c|}{ Public (CBE) } & \multirow{2}{*}{$\begin{array}{l}\text { Private } \\
\text { Agree } \\
(\%)\end{array}$} & \multirow[b]{2}{*}{ mean } \\
\hline & $\begin{array}{l}\text { Agree } \\
(\%)\end{array}$ & mean & & \\
\hline Loans default rate & $61.6 \%$ & 2.54 & $80.7 \%$ & 2.19 \\
\hline With growth in banks size comes growth on NPL & $54 \%$ & 2.85 & $73.1 \%$ & 2.35 \\
\hline The bank's lending policies always influences the lending decisions & $65.4 \%$ & 3.19 & $65.4 \%$ & 2.35 \\
\hline $\begin{array}{l}\text { Project appraising and selection officers and managers are qualified } \\
\text { and skilled enough }\end{array}$ & $77 \%$ & 2.15 & $84.7 \%$ & 1.69 \\
\hline $\begin{array}{l}\text { Credit performers in the bank have autonomous power in appraising } \\
\text { and selecting projects }\end{array}$ & $73 \%$ & 2.46 & $73 \%$ & 2.15 \\
\hline
\end{tabular}

Table 1 Factors Indicating Bank Size and Performance

Source: Survey outcome and own computation 2017

In the above Table, the results shows; loan default rate, with growth in bank size comes growth on NPLs, bank lending policy always influence the landing decision, is directly related to bank size for the occurrences of loan default. Based on this results the problem is higher in private bank when compared with state owned bank in terms of average mean $(2.29 \& 2.86)$ respectively .

The result of this study is supported by (Taiwan, $\mathrm{Hu}, \mathrm{Li}$ and Chu 2004), Bank size is negatively related to the 
rate of NPLs, which supports their argument that larger banks have more resources for determining the quality of loans.

1.7.1.2 Credit Size

Table 2 Factors Indicating Credit Size

\begin{tabular}{|l|l|l|l|l|}
\hline \multirow{2}{*}{ Items } & \multicolumn{3}{|l|}{ State owned (CBE) } & \multicolumn{2}{l|}{ Private Bank Dashen } \\
\cline { 2 - 5 } & Agreement (\%) & mean & Agreement (\%) & mean \\
\hline Aggressive lending & $73.2 \%$ & 2.23 & $92.3 \%$ & 1.46 \\
\hline Lack of Compromised integrity in credit approval & $65.4 \%$ & 2.19 & $80.8 \%$ & 2.00 \\
\hline Rapid credit growth & $65.4 \%$ & 2.27 & $69.2 \%$ & 2.15 \\
\hline The Banks great risk appetite & $73.1 \%$ & 2.15 & $84.6 \%$ & 1.81 \\
\hline Having large number of borrowers & $88.5 \%($ Disagree) & 3.65 & $77 \%$ (Disagree) & 3.38 \\
\hline
\end{tabular}

Source: Survey outcome and own computation 2017

In the above Table, the results shows; Aggressive lending, lack of compromised integrity in credit approval, rapid credit growth, the banks great risk appetite, is a problem which related to credit size for the occurrences of loan default. Based on the results this causes are higher in private bank when compared with state owned bank in terms of Average mean (1.85\& 2.21) respectively.

The result of this study is supported by Keeton and Morris (1987) indicated that commercial banks with greater risk appetite tend to record higher losses. This also leads to leniency.

Salas and Saurina (2002) attribute the leniency to disaster myopia, herd behavior and agency problems that may tempt bank managers to lend excessively during boom periods of economic expansion.

1.7.1.3 Credit Assessment

Table 3 Factors Indicating Credit Assessment

\begin{tabular}{|l||l|l|l||l|}
\hline Items & public (CBE) & \multicolumn{2}{l|}{ Private Bank } \\
\cline { 2 - 5 } & $\begin{array}{l}\text { Agreement } \\
(\%)\end{array}$ & mean & $\begin{array}{l}\text { Agreement } \\
(\%)\end{array}$ & mean \\
\hline Poor credit analysis & $88.4 \%$ & 1.96 & $100 \%$ & 1.65 \\
\hline $\begin{array}{l}\text { Know Your Customer (KYC) policy of banks lead to high } \\
\text { loans quality }\end{array}$ & $92.3 \%$ & 1.58 & $96.2 \%$ & 1.77 \\
\hline Good loan underwriting ensures loan performance & $100 \%$ & 1.62 & $92.3 \%$ & 1.65 \\
\hline Poor risk assessment & $84.6 \%$ & 1.85 & $96.2 \%$ & 1.73 \\
\hline
\end{tabular}

Source: Survey outcome and own computation 2017

In the above Table, the results show; Poor credit analysis and Poor credit risk assessment is related to poor credit assessment this indicates the causes for the occurrences of non-performing loans. In this regard the problem is higher in private bank when compared with state owned bank in terms of Average mean 1.69 and 1.91 respectively.

The result of this study is supported by (Gaitho Edna,2010, Teshome dula,2010, Wondimagegnehu. N, 2012) indicated that, Lax procedures used for credit risk assessment, poor credit appraisal and delayed loan approval and poor credit risk assessment had direct or significant effect for the occurrences of nonperforming loans in commercial banks.

1.7.1.4 Credit Monitoring

\begin{tabular}{|l||l|l|l||l|}
\hline Table 4 Factors Indicating Credit Monitoring Items & \multicolumn{2}{l|}{ Private Bank } \\
\cline { 2 - 5 } & $\begin{array}{l}\text { Agreement } \\
(\%)\end{array}$ & mean & $\begin{array}{l}\text { Agreement } \\
(\%)\end{array}$ & mean \\
\hline Strict monitoring ensures loan performance & $96.2 \%$ & 1.69 & $92.3 \%$ & 1.46 \\
\hline $\begin{array}{l}\text { Poorly assessed advanced loans may perform well if } \\
\text { properly monitored }\end{array}$ & $73 \%$ & 2.15 & $84.7 \%$ & 1.85 \\
\hline $\begin{array}{l}\text { Loan follow up is directly related to occurrence of non- } \\
\text { performing loans }\end{array}$ & $84.6 \%$ & 1.92 & $80.7 \%$ & 1.73 \\
\hline $\begin{array}{l}\text { Banks loan supervision capacity have lower non-performing } \\
\text { loans }\end{array}$ & $76.9 \%$ & 1.96 & $80.8 \%$ & 1.96 \\
\hline
\end{tabular}

Source: Survey outcome and own computation 2017

In the above Table, the output shows; Strict monitoring, poorly assessed advanced loans may perform well if properly monitored, loan follow up, loan supervision capacities are ensures loan performance, this is also related with effective monitoring to reduce NPLs. Up on this private bank are the most when compared with state owned bank with average mean of 1.75 and 1.93 respectively.

The result of this study is supported by (Agresti et al. 2008) stated that important of regular monitoring is to safe 
loan quality, it would help insure a sound financial system and there by prevent systemic risk that otherwise would lead to loan default.

1.7.1.5 Credit Terms and Condition

Table 5 Factors Indicating Credit Terms and Condition

\begin{tabular}{|l|l||l|l||l|}
\hline Items & Public Bank & Private Bank \\
\cline { 2 - 5 } & $\begin{array}{l}\text { Agreement } \\
(\%)\end{array}$ & mean & $\begin{array}{l}\text { Agreement } \\
(\%)\end{array}$ & mean \\
\hline Lenient/lax credit terms & $92.3 \%$ & 1.81 & $96.2 \%$ & 1.35 \\
\hline Poorly negotiated credit terms & $80.8 \%$ & 1.65 & $92.3 \%$ & 1.88 \\
\hline $\begin{array}{l}\text { Borrowers default because they do not understand the credit } \\
\text { terms well }\end{array}$ & $76.9 \%$ & 2.04 & $88.4 \%$ & 1.77 \\
\hline
\end{tabular}

Source: Survey outcome and own computation 2017

In the above Table, the output shows; Lenient/lax credit terms, poorly negotiated credit terms, borrowers default because they do not well understand the credit terms, are related with poor credit term and condition for the occurrences of loan default. The results indicated the highest in private bank when compared with state owned bank in terms of average mean 1.67 and 1.83 respectively.

The result of this study is supported by Rajan and Dhal (2003) who studied the Indian commercial banks also found out that lenient credit terms are determines occurrence of non-performing loans.

1.7.1.6 Inadequate Nature of Collateral

Table 6 Factors Indicating Inadequate Nature of Collateral

\begin{tabular}{|l|l|l|l|l|}
\hline \multirow{2}{*}{ Items } & Public Bank & \multicolumn{2}{l|}{ Private Bank } \\
\cline { 2 - 5 } & Agreement (\%) & mean & Agreement (\%) & mean \\
\hline Residential(housing) collateral & $57.7 \%$ (disagreement) & 2.96 & $57.7 \%$ & 2.62 \\
\hline Commercial(business) collateral & $61.5 \%$ & 2.31 & $69.2 \%$ & 2.35 \\
\hline Agricultural land collateral & $84.7 \%$ & 1.81 & $73.1 \%$ & 2.15 \\
\hline Collateral location & $69.2 \%$ & 2.15 & $73.1 \%$ & 2.00 \\
\hline
\end{tabular}

Source: Survey outcome and own computation 2017

In the above Table, the output shows; Residential (housing) collateral are related to inadequate nature of collateral in private bank. But in state owned bank doesn't agree for the statement. On the other hand commercial (business) collateral, agricultural land collateral, collateral location is reason for inadequate nature of collateral which causes loan default. These problems are almost equivalent in both banks.

This study is supported by (Gaitho Edna, 2010), the causes of non-performing loans in Kenyan banks, he reveled that poorly valued collateral or difficulties in recovery are factors contribute to bad loans.

1.7.1.7 Aggressive Credit Collection Policies

Table 7 Factors Indicating Lack of Aggressive Credit Collection Policies

\begin{tabular}{|l|l|l|l||l|}
\hline Items & Public Bank & \multicolumn{2}{l|}{ Private Bank } \\
\cline { 2 - 5 } & $\begin{array}{l}\text { Agreement } \\
(\%)\end{array}$ & mean & $\begin{array}{l}\text { Agreement } \\
(\%)\end{array}$ & mean \\
\hline Poor credit policies and procedure & $92.4 \%$ & 1.62 & $100 \%$ & 1.46 \\
\hline $\begin{array}{l}\text { No serious action will be taken against borrowers not to } \\
\text { repay the loan }\end{array}$ & $84.7 \%$ & 1.85 & $92.3 \%$ & 1.65 \\
\hline Length of repayment period & $84.7 \%$ & 1.96 & $77 \%$ & 1.92 \\
\hline $\begin{array}{l}\text { Any special terms such as seasonal dating and the collection } \\
\text { period of the firm }\end{array}$ & $84.7 \%$ & 1.81 & $84.6 \%$ & 2.04 \\
\hline
\end{tabular}

Source: Survey outcome and own computation 2017

In the above Table, the output shows; Poor credit policies and procured, no serious action will be taken against borrowers not to repay the loan, length of repayment period, and any special terms such as seasonal dating and the collection period of the firm are related with lack of aggressive credit collection polices, this is also causes for NPLs. The finding shows higher in private bank when compared with state owned bank in terms of average mean 1.78 and 1.81 respectively.

This study is supported by (Gaitho Edna, 2010), Stephen Laurent and Isaac Mwakajumilo,2014) the causes of non-performing loans in Kenyan banks and Tanzania specifically NMB Bank reveled that Lack of aggressive credit collection methods are causes for NPLs.

1.7.2 Customer Specific Factors Affecting NPLs

1.7.2.1 Customer Fund Diversion 
Table 8 Factors Indicating Customers Fund Diversion

\begin{tabular}{|l|l|l|l|l|}
\hline \multirow{2}{*}{ Items } & \multicolumn{2}{l|}{ Public Bank } & \multicolumn{2}{l|}{ Private Bank } \\
\cline { 2 - 5 } & Agreement (\%) & mean & Agreement (\%) & mean \\
\hline Lack of proper monitoring & $100 \%$ & 1.38 & $100 \%$ & 1.35 \\
\hline Ignorance of lending terms and conditions & $96.2 \%$ & 1.58 & $84.6 \%$ & 1.81 \\
\hline Over financing & $84.6 \%$ & 1.96 & $83.5 \%$ & 1.91 \\
\hline Under financing & $69.3 \%$ & 2.12 & $92.3 \%$ & 1.50 \\
\hline Anticipation of windfall profits in other business areas & $92.3 \%$ & 1.58 & $92.3 \%$ & 1.54 \\
\hline
\end{tabular}

Source: Survey outcome and own computation 2017

In the above Table, the output shows that; Lack of proper monitoring, ignorance of lending terms and conditions, over/ under financing, anticipation of windfall profits in other business areas are problems related to customers fund diversion these is also causes for the occurrences of NPLs in both banks.

The result of this study is supported by (Carlo Msigwa, 2013) studied Factors affecting non-performing loans in Banking industry: A case of KCB Bank (Tanzania) Limited; Morogoro and Msimbazi Branches. The findings showed that, diversion of funds for unnecessary expansion of business are the reason for loan defaults

1.7.2.2 Unwillingness of Borrower to Pay Back the Loans

Table 9 Factors Indicating Unwillingness of Borrower to Pay Back the Loans

\begin{tabular}{|l||l|l|l|l|}
\hline \multirow{2}{*}{ Items } & Public Bank & Private Bank \\
\cline { 2 - 6 } & Agreement (\%) & mean & Agreement (\%) & mean \\
\hline Lack of proper education in the business area & $84.6 \%$ & 1.73 & $84.6 \%$ & 1.92 \\
\hline Intentional (willful) defaults by borrowers & $84.6 \%$ & 1.96 & $88.5 \%$ & 1.96 \\
\hline Lack of sufficient supervision from the bank & $88.5 \%$ & 1.96 & $92.3 \%$ & 1.73 \\
\hline Market condition & $88.5 \%$ & 1.92 & $88.5 \%$ & 1.85 \\
\hline
\end{tabular}

Source: Survey outcome and own computation 2017

In the above table, the output shows; Lacks proper education in the business area, intentional (willful) defaults by borrowers, lack of sufficient supervision from the bank and market conditions are the major problems in both banks related to unwillingness of borrower to pay back the loans it was leads to the occurrences of loan default. The result of this study is supported by (Kanimbla, 2010) studied determinants of non- performing loans in Standard Charted Bank he argued that unwillingness of borrowers to pay back the loan, lack of business skills are the reasons for the occurrences of non-performing loans.

1.7.3 Remedial Mechanisms to Deal with NPLs

Table 10 Factors indicating remedial mechanisms to deal with NPLs

\begin{tabular}{|c|c|c|c|c|}
\hline \multirow[t]{2}{*}{ Items } & \multicolumn{2}{|c|}{ Public Bank } & \multicolumn{2}{|c|}{ Private Bank } \\
\hline & Agree & mean & Agree & mean \\
\hline $\begin{array}{l}\text { when banks ensure strict monitoring measures increases the chances of } \\
\text { loan performance }\end{array}$ & $96.20 \%$ & 1.65 & $92.3 \%$ & 1.85 \\
\hline Providing collateralized loans reduces the chances of loan defaults & $84.6 \%$ & 1.88 & $80.8 \%$ & 2.04 \\
\hline $\begin{array}{l}\text { allocation of more funds for loan monitoring leads to lower non- } \\
\text { performing loans }\end{array}$ & $73.1 \%$ & 2.00 & $84.6 \%$ & 1.96 \\
\hline $\begin{array}{l}\text { improving or providing effective risk assessment mechanisms leads to } \\
\text { quality loans }\end{array}$ & $80.8 \%$ & 1.88 & $88.5 \%$ & 1.85 \\
\hline Immediate transfer of NPL to ALD(loan and advance under litigation) & $76.9 \%$ & 1.96 & $80.8 \%$ & 2.08 \\
\hline
\end{tabular}

Source: Survey outcome and own computation 2017

In the above table, the output shows; In both banks ensure strict monitoring measures, adequate collateralized loan, allocation of more fund for loan monitoring, effective risk assessment and immediate transfer of NPL to ALD( loan under litigation) are indicated the remedial measures to deal with NPLs.

The result of this study is supported by (Babouček and Jančar 2005, Guy 2011 and Onsarigo, et al., 2013) contends several strategies and measures have been exploited by banks in order to deal with NPLs. For instance conducting effective risk assessment before availing loans to clients has been cited as a fundamental mechanism of dealing with NPLs.

\subsection{Conclusion}

Regarding institutional specific factors, the finding concluded that;

Bank size and performance due to; loan default rate, with growth in bank size come growth on NPLs, lending policies affect the lending decision.

credit size due to; aggressive lending, lack of compromised integrity in approving credit, rapid credit growth and 
bank's excessive or great risk appetite.

Poor credit assessment due to; weak credit analysis and poor credit risk assessments and Poor Credit terms and condition due to; lenient/lax credit terms, poorly negotiated credit terms and borrowers default due to lack of well understanding the credit terms.

Inadequate nature of collateral due to; Residential, commercial, agricultural and collateral location. Lack of aggressive credit collection policies due to; Poor credit policies \& procedure, no serious action will be taken against borrowers not to repay the loan, length of repayment period, any special terms such as seasonal dating \& collection period of the firms.

Regarding customer specific factors the results concluded that; Customer fund diversion due to; Lack of proper monitoring, ignorance of lending terms, over \& under financing, anticipation of windfall profits in other business areas. Unwillingness of borrower to pay back loan due to; Lack of proper education in the business area, intentional(willful) defaults by borrowers, luck of sufficient supervision from the bank, market condition.

Based on the above conclusion private bank are higher in related with the problem for the occurrences of NPLs when compared with state owned banks.

\subsection{Recommendation}

In general to reduce the occurrence of loan default it suggests that, in state owned and private Banks in the region; should clearly \& effectively communicating with lending officers regarding policies \& procedure and ensure to discount future occurrences of credit risk or loss. should strengthen its applicant screening criteria and due diligence assessment to select potential risk taking applicants. Should adopt appropriate pre and post credit risk assessments.

Banks needs to ensure that borrowed funds are being used for the intended purpose through enhanced timely credit monitoring after the loan is being disbursed. should prevent a sharp buildup of NPL in the future by ensuring that;- Avoiding excessive lending,Maintaining high credit standards/terms, Closely monitor the rate of credit growth to prevent aggressive lending. should consider some ways of controlling the chances of NPLs with monitoring how costumers repay loans before providing them with new loans. Finally, the stakeholders in the credit system including the banks \& government must implement policies that will facilitate the minimization of the internal as well as external factors that precipitate NPLs.

\section{Reference}

Ahmmed, M., Serajul,I., \&Rahman, M.T. (2012). Analysis of Repayment Behavior in Banks Customer Perspective. Case of Bangladeshi Mercantile Limited Bank, World Review of Business Research, Volume 2.

Anisa, U. (2015): conducted on the Determinants of Nonperforming Loan in Ethiopian Commercial Banks. Addis Ababa University, February, 2015, Addis Ababa. Ethiopia. Unpublished

Arega, S.,Asfaw, H., Nigussie, B.\&Tadele, T.T. (2016). Factor affecting nonperforming loans in development bank central regime. Jimma University, Jimma, Ethiopia. International Journal of Scientific and Research Publications, Volume 6, Issue 5, May 2016. 656 ISSN 2250-315.

Amir, I., Qin,s. andmuhammed,F. (2016): Determinants of non-performing loans: An empirical investigation of bank specific and micro economic factors. Xi anjiaotong university china. The journal of applied business research Nov/Dec, 2016. Volume 32

Babouček, I. \&Jančar, M. (2005). Effects of Macroeconomic Shock to the Quality of the Aggregate Loan Portfolio. Czech National Bank, Working Paper Series, No. 1, pp.1-62.

Brownbrigde, M. (1998). The Causes of financial distress in local banks in Africa and implication for prudential policy, unctad/osg/dp/132.

Bercoff, Jose J., Julian di, Giovanni \&Franque, G. (2002). "Argentinean Banks, Credit Growth and the Tequila Crisis: A Duration Analysis" (Unpublished)

Carlo, M. (2013): factors affecting non-performing loans in banking industry; A case of KCB Bank Tanzania Limited, Morogoro and MsimbaziBranckes. Mzumbe University, Tanzania. (Unpublished).

Conradie, W.M. \&Fourie, C.M.W.(2002): Basic Financial Management for Entrepreneurs, $2^{\text {nd }}$ edition. Lansdowne: Juta\& Co.

Directives of National Bank of Ethiopia (2002): Draft guidance to banks on non-performing loans, AdiseAbaba, Ethiopia. - Annex 7.

Fatemi, A. \&Fooladi, I. (2006). “Credit Risk Management: A Survey of Practices. Managerial Finance. Vol.32, No. 3, pp.227 - 233.

Fofack, H. (2005), Non-Performing Loans in Sub-Saharan Africa: Causal Analysis and Macroeconomic Implications, World Bank Policy Research Working Paper No. WP3769.

Gaitho, E. (2010); cases of nonperforming loans in commercial banks in Kenya banks. University of Nairobi, Kenya. Unpublished

Gehrig, T. \&Stenbacka, R. (2007). Information sharing and lending market competition with switching costs and 
poaching', European Economic Review, 51: 77-99.

Gebru, M. (2015): conducted on Determinants of Non-Performing Loans: The Case of the Ethiopian Commercial Banks. Addis Ababa University, Addis Ababa. Ethiopia.Unpublished.

Harris, P. (2003): A banker's view of BEE. Briefing to Business Map Foundation members, Johannesburg, July 25, 2003.http://www.businessmap.co.za [accessed on January, 05,2017, 04: 30 :15 PM]

Heffernan, S. (1996): Modern banking in theory and practice. John Wiley and Sons, Chichester.

Hoque, M.Z. \&Hossain, (2008).Flawed interest rate policy and loan defaults: Experience from developing countries. International review of business research papers, Col.5, No.5, 235-246.

Habtamu, G. (2015): conducted on assessment of factors affecting non-performing loan the case of Ethiopian privet bank, Addis Ababa University, Ethiopia. Unpublished.

John, M.,\& John, B.(1994):Credit Risk Management, In their Strategic publication

International Monetary Fund. (2009a): Initial lessons of the crisis. IMF Staff Paper 09/37.international Monetary Fund, Washington, DC.

International Monetary Fund. (2009b): Lessons of the global crisis for macroeconomic policy.IMF Staff Paper 09/37. International Monetary Fund, Washington, DC.

Jappelli, T. \& Pagano, M. (2005): Role and Effects of Information Credit Sharing. Cambridge: The MIT Press. Available from: http://www.csef.it/WP/wp136.pdf [Accessed January, 09, 2017, 02:23:42 PM].

Jimenez, G. and Saurina, J. (2005), “Credit cycles, credit risk, and prudential regulation”, Banco de Espana, May 2007.

Kallberg, J. \&Udell, G. (2003). The value of private sector business credit information sharing: the US case, Journal of Banking and Finance, 27: 449-469.

Karim, M. Z. A., Chan, S. G., \& Hassan, S. (2010): “Bank Efficiency and Non-Performing Loans: Evidence from Malaysia and Singapore”, Prague Economic Papers 2.

Keeton W. \& C. S. Morris. (1987). Why Do Banks' Loan Losses Differ? Federal Reserve Bank of Kansas City, Economic Review, May, pp. 3-21.

Khemraj, T. \& Pasha, S. (2009). The Determinants of Non-Performing Loans: A Case Study of Guyana. New York, NY: Routledge.

Khemraj\& Pasha 2009. "The determinants of Nonperforming loans: An econometric case study of Guyana.”MunichPersonal Re PEC Archive Paper No.53128.

LaPorta, R., F. Lopez-de, S., \&Shleifer, A. (2000).Government Ownership of Banks. NBER Working Paper 7620, National Bureau of Economic Research, Cambridge, Massachusetts.

Louzis, D. P, Vouldis, A. T, \& Metaxas, V. L. (2011): Macroeconomic and bank-specific determinants of nonperforming loans in Greece: A comparative study of mortgage, business and consumer loan portfolios. Journal of Banking \& Finance, 36(4), 1012-1027.

Lu, D., Thangavelu, S. M. \& Hu, Q. (2011): "Biased Lending and Non-Performing Loans on China's Banking Sector", Journal of Development Studies. Pp. 1072 - 1091.

Mac Donald, S.S. \& Koch, T.W. (2006), Management of Banking, 6 th edition, U.S.A: Thomson - South Western.

Machiraju, HR. (2001). Modern Commercial Banking, India: VIKAS Publishing House Pvt. Ltd. C.

Messai, A. S. \&Jouini, F. (2013): "Micro and Macro Determinants of Non-Performing Loans", International Journal of Economics and Financial Issues. Vol. 3, No. 4, pp. 852-860.

Makri, V., Tsagkanos, A., \&Bellas, A. (2014). Determinants of non-performing loans: The case of Eurozone. Panoeconomicus, 61(2), 193-206.

Ming-chang, C., Chien-Chi, L., Quynhnhu, N.T. \&Hui-Yu, C. (2016): Factors affects non-performing loans in Taiwan Bank industry: National Chung Cheng University, Taiwan. Journal of accounting, finance and economics: Vol. 6, No 1. Murch, 2016. Pp. 65-87.

Monicah, W.M. (2013); cases of nonperforming loans in commercial banks in Kenya. University of Nairobi. Kenya. Unpublished.

Nkusu, M. (2011): Nonperforming Loans and Macro financial Vulnerabilities in Advanced Economies. IMF Working Paper 11/161.

NBE (National Bank of Ethiopia) (2009): financial reporter guideline Directive No. SBB/38/2009. National Bank of Ethiopia, Addis Ababa.Ethiopia.

NBE (National Bank of Ethiopia) (2008): Conference Proceedings on National Payment System: Asset Classification and Provisioning Directive No. SBB/43/2008. National Bank of Ethiopia, Addis Ababa, Ethiopia.

Richard, E. (2011). Factors That Cause Non-Performing Loans in Commercial Banks in Tanzania and Strategies to Resolve Them. Journal of Management Policy and Practice 12(7) 2011.

Teshome, D. (2010): non-performing loans and its Management in commercial bank in Ethiopia a case Dashen Bank Mekelle area bank. Mekelle University June, 2010, Mekelle, Ethiopia. Unpublished. 
Tesfa, G. (2016): conducted on "Determinants of Ethiopian Private Commercial Banks Asset Quality" Addis Ababa University April, 2016, Addis Ababa. Ethiopia. Unpublished.

Warue, B. J. (2013). "The Effects of Bank-Specific and Macro Economic Factors on Non-Performing Loans in Commercial Banks in Kenya: A comparative Panel Data Analysis”, Advances in Management and Applied Economics. Vol. 3, No. 2, pp. $135-164$.

Wondimagegn, N. (2012). Determinants of NPL in Ethiopian Banks, MBA Graduation paper, University of South Africa. 